\title{
Utilization of ash from power plants for high embankments on soft soil
}

\author{
Sanja Jocković1,*, Veljko Pujevićn ${ }^{1}$, and Miloš Marjanović ${ }^{1}$ \\ ${ }^{1}$ Faculty of Civil Engineering, University of Belgrade, Bulevar kralja Aleksandra 73, Belgrade, Serbia
}

\begin{abstract}
The ash landfills are a major environmental issue. The use of ash for the highway and railway substructure achieves a double benefit: it significantly reduces the deposited quantities of ash as well as the consumption of natural materials such as crushed stone, gravel and sand. The investigation of engineering properties of fly ash from the power plant in Serbia was conducted at the Laboratory of Soil Mechanics at the Faculty of Civil Engineering in Belgrade. Relevant physical and mechanical properties of ash and mixtures with binders (cement/lime) were investigated. The ash was also tested from the aspect of the potential environmental impact, which primarily depends on the leaching behaviour of the present trace elements. The results of the study showed that fly ash meets technical and environmental requirements and that has the potential for use in highway substructure, such as construction of embankments and stabilization of soft soils. Benefits of utilization of ash and slag was shown in the case of the construction of a high embankment on soft soil on the highway section Obrenovac-Ub in Serbia.
\end{abstract}

\section{Introduction}

Fly ash is a by-product of coal burning in thermal power plants. Fly ash is a pozzolan, that is, silicate or aluminum-silicate material that combines with calcium hydroxide in isolated form and in the presence of water (from lime, Portland cement or dust from the calcinator) forming compounds with binding properties. Fly ashes from Serbian power plants have pozzolanic properties and, because of low concentrations of calcium compounds (less than $10 \% \mathrm{CaO}$ ), they are devoid of self-cementing characteristics. According to standard ASTM C 618, these ashes belong to class F and according to European Standard EN 197-1, they are classified as siliceous (type V) ashes. Class F fly ash should be used in soil stabilization with the addition of cementitious agent like such as lime, lime kiln dust, cement, cement kiln dust [1]. However, many researches indicating that this fly ash can effectively improve some engineering properties of soil without activators (binders) [2-7]. Approximately 7 million tons of fly ash and slag are produced every year in Serbian power plants. Very small percentage is used in the cement industry, while over $90 \%$ of the obtained amount is deposited in landfills [8-9].

\footnotetext{
* Corresponding author: borovina@grf.bg.ac.rs
} 
Since the construction of traffic (transport) infrastructure requires significant amounts of natural construction material (earth material, sand, gravel, crushed stone), the use of large quantities of ash would have environmental, economic and practical significance. Any reduction of deposits of fly ash and its reuse brings multiple benefits such as: natural resources savings, preventing ecosystem change, reduction of pollution of soil, underground and surface waters and air by selecting the appropriate method of installation of this material. Also, energy is saved for exploitation, crushing and grinding of stone material of standard quality. Utilization of fly ash in civil engineering results in significant economic effects, since ash and slag are cheap materials, and the installation method is relatively simple.

The objective of this research was to investigate of engineering properties of fly ash from the power plant „Nikola Tesla B“ (TENT B) in Serbia and to investigate benefits of utilization of ash in the case of the construction of a high embankment on soft soil. The investigation was conducted at the Laboratory of Soil Mechanics at the Faculty of Civil Engineering in Belgrade, as the part of the research project funded by Electric Power Industry of Serbia $[10,11]$.

\section{Testing methods}

Material used for the experimental research program include fly ash from thermo-electric power plant „Nikola Tesla B“ (TENT B). Commercially available low heat sulfate resistant cement $(32.5 \mathrm{~N})$ and lime ,Jelen Do“ were used as activators. The grain size distribution for the fly ash is shown in Table 1 .

Table 1. Grain size distribution of fly ash

\begin{tabular}{|c|c|c|c|c|c|}
\hline $\mathrm{G}_{\mathrm{s}}$ & $\begin{array}{c}\text { Clay } \\
<0.002 \mathrm{~mm}\end{array}$ & $\begin{array}{c}\text { Silt } \\
0.002-0.06 \mathrm{~mm}\end{array}$ & $\begin{array}{c}\text { Sand } \\
0.06-2.0 \mathrm{~mm}\end{array}$ & $\begin{array}{c}\text { Gravel } \\
2.0-60.0 \mathrm{~mm}\end{array}$ & $\begin{array}{c}\text { Fractions } \\
<0.075 \mathrm{~mm}\end{array}$ \\
\hline $2.24-2.27$ & 2 & $40-41$ & $57-58$ & 0 & $49-50$ \\
\hline
\end{tabular}

Following laboratory investigations were used to determine the physical and mechanical properties of the ash: specific gravity, grain size distribution, moisture-density relationship (Proctor compaction test), unconfined compressive strength test (UCS), direct shear test and CBR test. All tests were performed on two or three specimens, according to SRPS and EN standards. Laboratory testing was performed on four combinations of materials and binders, Table 2. Minimum percentage of used cement is determined regarding the uniformity of the mixture with minimum cement consumption, while the minimum amount of lime was set from the condition that the $\mathrm{pH}$ value of mixture shall be 12.4 , securing the optimal conditions for the hydration process.

Table 2. Percentage of binders

\begin{tabular}{|c|c|c|}
\hline \multirow{2}{*}{ Material } & \multirow{2}{*}{ Binder } & \% of binder (\% of dried soil weight) \\
\hline \multirow{3}{*}{ TENT B } & \multirow{2}{*}{ Cement } & 2 \\
\cline { 2 - 3 } & \multirow{2}{*}{ Lime } & 4 \\
\cline { 2 - 3 } & & 5 \\
\hline
\end{tabular}

Material without binders was tested first, in order to determine initial physical and technical properties - etalons, used later on to compare properties of stabilized material. In order to be able to compare stabilization results with different percentages of binders, it was necessary to prepare samples with the same initial conditions. Testing specimens were prepared by compaction at optimum moisture content from Standard Proctor compaction test, 
Table 3. Premeasured amount of fly ash and binders (\% of dried fly ash) were mixed thoroughly to produce a homogeneous mixture and then water was added to reach optimum moisture content. After mixing, mixture was compacted without delay. Specimens with the addition of cement were kept hermetically closed prior to testing in plastic wrap, while the specimens with the addition of lime were not hermetically closed.

Change of mechanical properties of stabilized material in time was tested on specimens that are 1, 7 and 28 days old. Unconfined compressive strength (UCS) tests were performed on test bodies that are $15 \mathrm{~min}, 1 \mathrm{~h}, 2 \mathrm{~h}$ and $4 \mathrm{~h}$ old, to obtain a more detailed information on the strength increment over time. In order to test the resistance of the stabilized material to frost, UCS tests were performed on samples 28 days old, after 15 freezing and melting cycles.

Table 3. Results of Standard Proctor test

\begin{tabular}{|c|c|c|c|c|}
\hline Material & Binder & $\begin{array}{c}\% \\
\text { of binder }\end{array}$ & $\begin{array}{c}\text { Wopt } \\
\%\end{array}$ & $\begin{array}{l}\gamma_{\mathrm{d}, \max } \\
\mathrm{kN} / \mathbf{m}^{3}\end{array}$ \\
\hline \multirow{5}{*}{ TENT B } & - & 0 & 33.7 & 10.37 \\
\hline & \multirow{2}{*}{ Cement } & 2 & 34.3 & 10.42 \\
\hline & & 4 & 33.0 & 10.58 \\
\hline & \multirow{2}{*}{ Lime } & 5 & 33.5 & 10.59 \\
\hline & & 7 & 33.0 & 10.62 \\
\hline
\end{tabular}

\section{Test results and discussion}

\subsection{Unconfined compressive strength (UCS)}

The results of UCS tests are presented in Figure 1. Fly ash sample without the addition of binders (etalon) has very low UCS $(87 \mathrm{kPa})$. With the addition of binders and water, the pozzolan reaction starts and results show constant strength gain over time. Four hours after compaction, UCS was increased up to $65-140 \%$, compared to ash etalon. With the addition of lime, the strength gain effect is more pronounced.

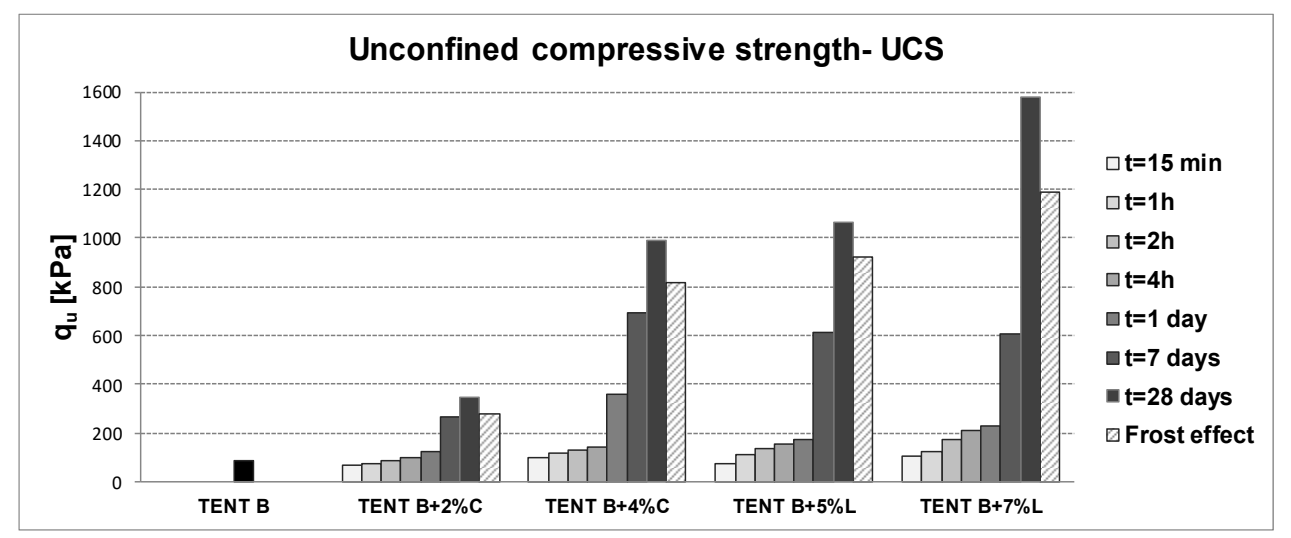

Fig. 1. Unconfined compressive strength

\subsection{Effect of frost}

Resistance of stabilized fly ash was tested related to frost by the method of determining reduction of UCS. After 15 cycles or freezing and melting, UCS of samples was determined 
and results are presented in Figure 1. Resistance index towards frost is within 75-86\%. Index value is acceptable taking into account large absolute values of UCS.

\subsection{Shear strength parameters in terms of effective stresses}

Effective parameters of shear strength are determined by the direct shear test and they are presented in Figure 2. Fly ash etalon has a high value of internal friction angle of $33.5^{\circ}$. Test results show mild increase of the angle of shearing resistance for all samples over time and with the increase of binder percentage. With the addition of cement the angle of shearing resistance was increased by $15-25 \%$, while the increase of $25-30 \%$ was noted with the addition of lime.

Fly ash has only the apparent cohesion as the result of approximation of non-linear failure envelope with linear one. After adding binders and with the addition of water pozzolan reaction occurs as well as creation of cement joints. Increment of cohesion over time is evident. By adding $2 \%$ of cement, cohesion was increased twice, and four times after adding $4 \%$ of cement (after 28 days). By adding lime, after 7 days, cohesion was increased 2.5-3.5 times where further increase of cohesion over time was not noticed.
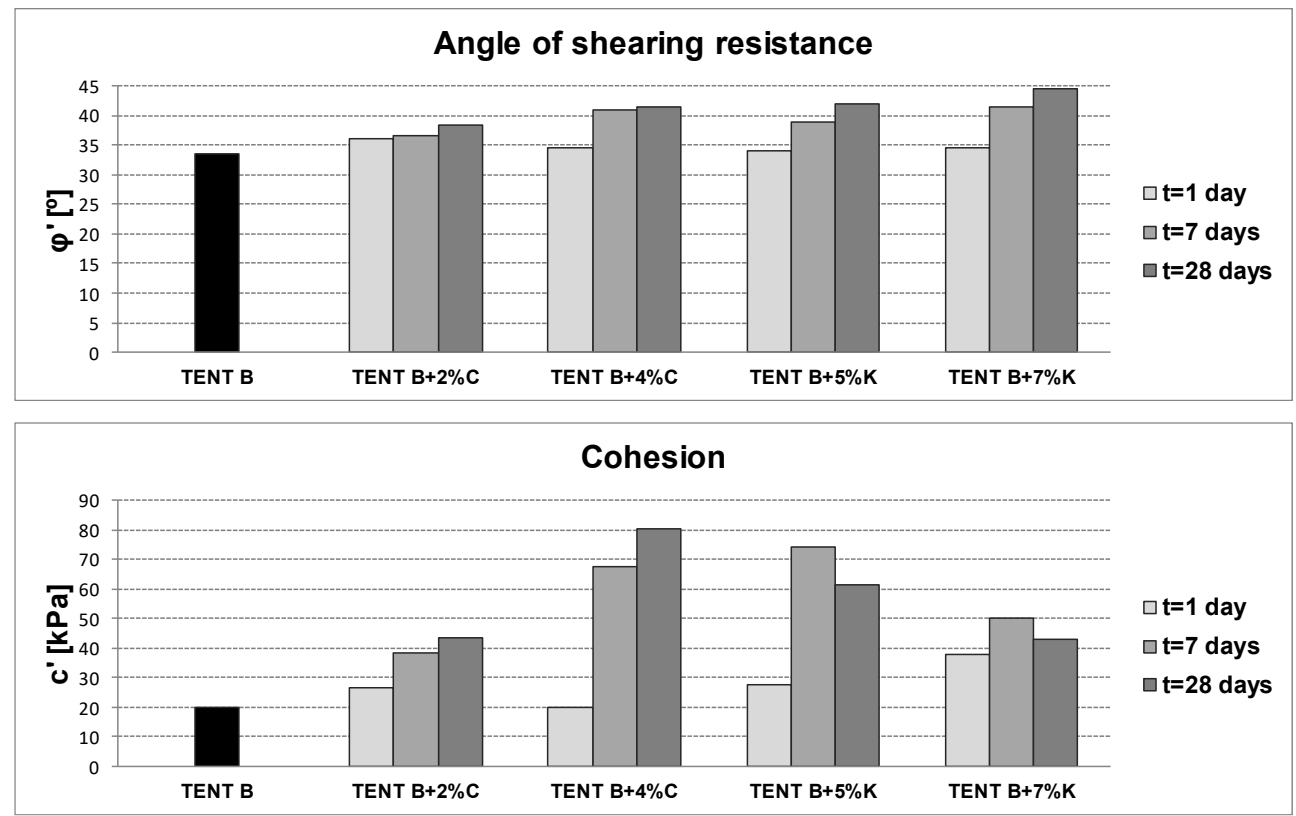

Fig. 2. Shear strength parameters in terms of effective stresses

\subsection{California bearing capacity - CBR}

Fly ash etalon has the CBR value of $12 \%$. With the presence of binders, for all tested samples, there is a clear trend of CBR increase over time. With the addition of cement CBR increase of 10-11 times was observed after 28 days, depending on binder amount. Similar effect was observed with the addition of lime - CBR value was increased 13-16 times, depending on binder amount. Results are shown in Figure 3. 


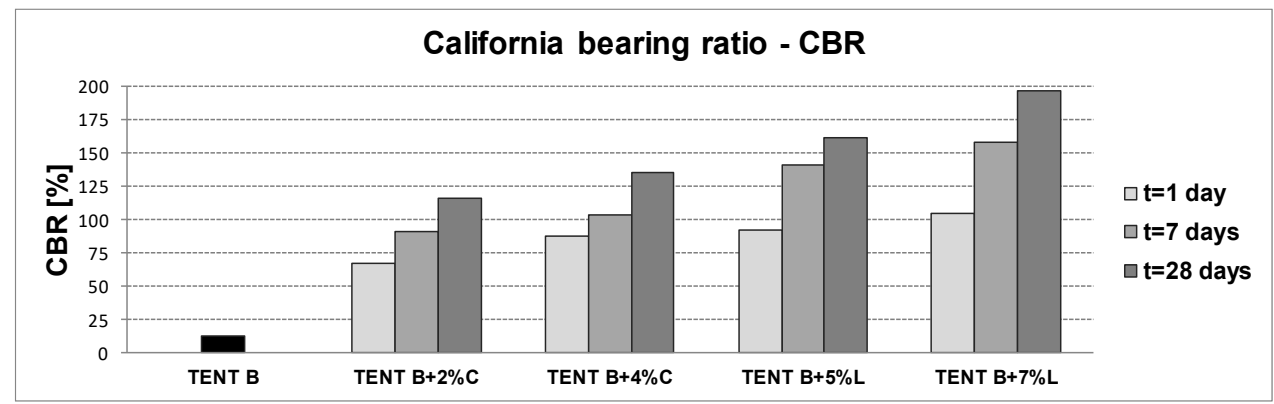

Fig. 3. California bearing ratio - CBR

\section{Ecological aspects of the fly ash utilization}

Before the practical utilisation of fly ash for the construction of the highway substructure, the risk of leaching of hazardous substances must be investigated. If it is proven that there is no leaching of hazardous substances that threaten the environment, utilisation of fly ash and slag would lead to multiple environmental and economic effects.

The essential requirements that fly ash and slag should fulfil for use in civil engineering from the standpoint of the environment is the content of radionuclides and trace elements that do not exceed prescribed limits.

According to [12], industrial waste material should not be disposed in the environment if the content of natural and artificial radionuclides is greater than the prescribed limits of radioactive contamination. Fly ash from TPPs in Serbia meet the prescribed criteria [13]. Fly ash is viewed as a great potential source for release of many environmentally hazardous elements. From the environmental aspect, the main concern should be directed towards As, $\mathrm{B}, \mathrm{Cr}$, Mo and Se. These elements could enter the nearby soil, freshwater and/or marine ecosystems. Assessing the environmental influence of products based on the content of trace elements leads to unreliable and highly overestimated predictions of the risk level which would limit fly ash utilisation. The potential environmental impact of fly ash depends on the leaching behaviour of the trace elements. There are appropriate solutions for the reduction of the leaching of some toxic trace elements such as As, B, Cr, Sb and Se [14].

\section{The benefits of the use of fly ash}

\subsection{Geotechnical conditions for the construction of the Ub-Obrenovac route}

Benefits of using fly ash are presented on an example of high embankments on the soft soil on the road section Ub-Obrenovac, Serbia. The considered highway section Ub-Obrenovac is $22 \mathrm{~km}$ long and is mostly located on alluvial plains of rivers Kolubara, Tamnava and Ub. The section on embankments is of variable height from 3.0-12.0 m.

The surface layers of the soil $(0.5-3.0 \mathrm{~m})$ include alluvial deposits of soft to moderately soft clays and muds of low to high plasticity and loose sands, while deeper layers include well compacted sands and gravely sands. Surface layers have very weak mechanical characteristics, low bearing capacity and high compressibility. Underground water is at the depth of 0.5-3.0 $\mathrm{m}$ from the surface.

According to project, the construction of embankments from sand and gravel with slope inclination of 1:2 is planned. Using geotechnical models, consolidation settlements of soil under embankments are calculated and presented in Table 4. 
Table 4. Settlements of embankments

\begin{tabular}{|c|c|c|c|c|}
\hline \multirow{2}{*}{$\begin{array}{c}\text { Station } \\
(\mathrm{km})\end{array}$} & \multirow{2}{*}{$\begin{array}{c}\text { Embankment height } \\
(\mathrm{m})\end{array}$} & \multicolumn{2}{|c|}{$\begin{array}{c}\text { Settlements } \\
(\mathrm{cm})\end{array}$} & \multirow{2}{*}{$\begin{array}{c}\text { Time of consolidation } \\
(\mathrm{months})\end{array}$} \\
\cline { 3 - 4 } & 7 & sand & ash & 4 \\
\hline $16+060$ & 8.5 & 38.8 & 24.2 & 4 \\
\hline $16+225$ & 5.5 & 27.10 & 16.9 & 9 \\
\hline $18+575$ & 5.5 & 14.8 & 9.2 & 2 \\
\hline $20+200$ & 5.5 & 7.2 & 4.5 & 7 \\
\hline $22+350$ & 12 & 38 & 23.7 & 7 \\
\hline $27+300$ & 6.2 & 12.5 & 7.8 & 4 \\
\hline $30+375$ & 8 & 41.0 & 25.6 & 7 \\
\hline $36+375$ & & & & \\
\hline
\end{tabular}

Calculated settlements are from 7.2 - $41 \mathrm{~cm}$ with consolidation period of 4 - 9 months. Calculation shows that on some sections large and long-term settlements of embankments is predicted, as well as different settlement time for certain sections. Considering the fact that 14 objects are planned to be constructed on this section (bridges, over and under passes) such geotechnical conditions may cause difficulties for design of road longitudinal level.

\subsection{Comparison of mechanical characteristics of sand and ash embankments}

Technical characteristics of material important for embankment design and the dimension of road construction are: California Bearing Ratio (CBR) (important for determination of road construction) and parameters of shearing resistance $\varphi$ ' and c' (important for determination of inclination of embankment slope).

According to main design, embankments are made of sand from the borrow pit near Ub, since that material meets the prescribed standards. Values of CBR and parameters of shearing resistance are given in column 1 of Table 5.

Table 5. Characteristics of materials

\begin{tabular}{|c|c|c|c|}
\hline $\begin{array}{c}\text { Technical } \\
\text { characteristics }\end{array}$ & $\begin{array}{c}\text { Sand and gravel from borrow } \\
\text { pit „Provalije" near Ub }\end{array}$ & Fly ash - TENT B & Fly ash with binders \\
\hline CBR & $11 \%$ & $12 \%$ & $115-197 \%$ \\
\hline$\omega_{\text {opt }}$ & $19 \%$ & $33.7 \%$ & $33-34.3 \%$ \\
\hline$\gamma$ & $20 \mathrm{kN} / \mathrm{m}^{3}$ & $12.8 \mathrm{kN} / \mathrm{m}^{3}$ & $12.8 \mathrm{kN} / \mathrm{m}^{3}$ \\
\hline$\varphi^{\prime}$ & $36^{0}$ & $33.5^{0}$ & $38.5-44.5^{0}$ \\
\hline$c^{\prime}$ & $0-12 \mathrm{kN} / \mathrm{m}^{2}$ & $20 \mathrm{kN} / \mathrm{m}^{2}$ & $43.5-80.5 \mathrm{kN} / \mathrm{m}^{2}$ \\
\hline
\end{tabular}

Fly ash whose mechanical properties are presented in the paper is deposited in silos that are nearest to the location of the Obrenovac-Ub road section. Comparable mean values of mechanical properties of ash with and without binders are given in Table 5 in the right column. Fly ash has larger CBR value as well as larger shearing resistance. According to these criteria the fly ash is better material than sand from the borrow pit, since the thickness of road construction and inclination of embankment slope can be reduced.

Optimum moisture content $\left(\mathrm{w}_{\mathrm{opt}}\right.$ ) of fly ash is expectedly much larger than the sand, which means that ash requires 2.5 times more water on the field. Since the soil on this section is water filled, securing sufficient water should not be a technical issue. 
Bulk density $(\gamma)$ of compacted sand is 1.6 times larger than the bulk density of ash, which provides significant advantage to the ash embankment for the following reasons: lower weight of ash embankment reduces settlements of subsoil, so the predicted settlements are in the range $4-25 \mathrm{~cm}$ (Table 4) instead $7-41 \mathrm{~cm}$ which is valid for sand embankment.

If subsoil stabilization was to be performed with fly ash, this would additionally reduce settlements, by $30 \%$ on average, since the largest deformation of subsoil happen in the surface low bearing and compressible layer. This would lead to maximum settlements of 14-16 cm and the differential settlements can be significantly reduced.

\section{Conclusions}

Although non self-cementing class F fly ash is most commonly used with addition of lime or cement, the results of laboratory tests have shown that the tested ash has relatively high shear strength parameters and CBR values. With the addition of binders, tested engineering properties are significantly improved, which confirms the efficiency of applying binders as stabilizers. Test results show that lime addition as activator, results in more significant improvement of engineering properties, than the cement addition.

Based on the presented research of possibilities of fly ash application for traffic (transportation) infrastructure, significant economic effects can be achieved, considering the large amount of planned earthworks. We have compared the mechanical properties of the natural material (sand) from the borrow pit and fly ash with the addition of binders (cement/lime), as well as the estimated settlement of the subsoil. The estimated subsoil settlements under ash embankment were significantly reduced. Mechanical properties of fly ash satisfy all technical conditions for embankment construction and fly ash has better relevant mechanical properties than natural material. The use of ash achieves a threefold benefit: amount of fly ash on landfills is reduced, natural resources are preserved, price of ash embankment is much lower than the price of sand embankment if the transport of ash has no significant impact on total price of used material.

On the other hand, fly ash is viewed as a great potential source for release of many environmentally hazardous elements and attention must be devoted to find appropriate solutions for the reduction of the leaching of some toxic trace elements.

\section{References}

1. American Coal Ash Association, Fly ash facts for highway engineers, Technical Report No. FHWA-IF-03-019, FHWA, USA, (2003)

2. N. S. Pandian, K. C. Krishna, B. Leelavathamma, Effect of fly ash on the CBR behaviour of soils, Indian Geotechnical Conference, Allahabad (2002)

3. T. L. Ramadas, N. D. Kumar, G. Yesuratnam, A study on strength and swelling characteristics of three expansive soils treated with fly ash, International Symposium on Ground Improvement (IS-GI Brussels 2012) - Recent Research, Advances \& Execution Aspects of Ground Improvement Works, Brussels (2012)

4. P. K. Kolay, H. Y. Sii, S. N. L. Taib, Int. J. of Civil and Environmental Engineering, 3 (2), 79-83 (2011)

5. S. M. Prasanna Kumar, Cementitious compounds formation using pozzolans and their effect on stabilization of soils of varying engineering properties, 2011 Int. Conf. on Environment Science and Eng. IPCBEE, Singapore (2011)

6. M. Vukićević, S. Maraš-Dragojević, S. Jocković, M. Marjanović, V. Pujević, Research results of fine-grained soil stabilization using fly ash from Serbian electric power plants, 
Proceedings of the 18th International Conference on Soil Mechanics and Geotechnical Engineering "Challenges and Innovations in Geotechnics", Paris, France, 3267-3270 (2013)

7. M. Vukićević, V. Pujević, M. Marjanović, S. Jocković, S. Maraš-Dragojević, GRAĐEVINAR, 67 (8), 761-770, doi: https://doi.org/10.14256/JCE.1281.2014 (2015)

8. S. Cmiljanić, S. Jotić, S. Tošović, Prethodni rezultati istraživačko razvojnog programa primena elektrofilterskog pepela u putogradnji, Institut za puteve, 37, pp. 41-49, (2008)

9. S. Cmiljanić, V. Vujanić, B. Rosić, B. Vuksanović, S. Tošović, S. Jotić, Physicalmechanical properties of fly-ash originating from thermo-electric power plants of Serbia, 14th Danube-European Conf. on Geotechnical Engineering: From Research to Design in European Practice, Bratislava, (2010)

10. M. Vukićević, Z. Popović, J. Despotović, L. Lazarević, Transport, 33 (2), 389-396, (2016)

11.Z. Popović, L. Lazarević, M. Vukićević, M. Vilotijević, N. Mirković, The modal shift to sustainable railway transport in Serbia, MATEC Web of Conferences 106, (2017)

12. Pravilnik o granicama radioaktivne kontaminacije životne sredine i o načinu sprovođenja dekontaminacije (in Serbian), Federal Republic of Yugoslavia, Official Gazette of FRY, 9/99. (1999)

13. M. Vilotijević, M. Vukićević, L. Lazarević, Z. Popović, Sustainable railway infrastructure and specific environmental issues in the republic of Serbia, Technical Gazette, 25/ 1. 2, (2018)

14. M. Izquierdo, X. Querol, International Journal of Coal Geology, 94, 54-66. https://doi.org/10.1016/j.coal.2011.10.006) (2012) 